Original scientific paper

\title{
IMPLEMENTATION OF THE LEAN CONCEPT AND SIMULATIONS IN SMES - A CASE STUDY
}

\author{
Tanasic, Z. ",\#. Janjic, G. .; Sokovic, M. ${ }^{* *} \&$ Kusar, J.* \\ ${ }^{*}$ Faculty of Mechanical Engineering, University of Banja Luka, Stepe Stepanovića 71, \\ 78000 Banja Luka, Bosnia and Herzegovina \\ ${ }^{* *}$ Faculty of Mechanical Engineering, University of Ljubljana, Aškerčeva 6, 1000 Ljubljana, Slovenia \\ E-Mail: zorana.tanasic@mf.unibl.org ( ${ }^{\#}$ Corresponding author)
}

\begin{abstract}
Increasing competition and globalization that encompasses all dealings in the world of business compel SMEs to seek more successful organizational and management modes and approaches. This paper presents a simulation model for the application of Lean methods and tools in SMEs and their impact on the improvement of production processes and product sustainability. The Lean concept can be used to achieve more efficient production whilst manufacturing lower-cost products including shorter manufacturing cycle, high quality, and added value. Research results show the usefulness of the application of dynamic simulations in the detection of critical places in processes and the usefulness of the application of relevant Lean methods and Lean tools for process improvement. Simulation results underline better performance of product manufacturing through the use of Lean tools with the aim to eliminate any waste. Reengineering the assembly line focuses on the following aspects, namely reducing waste, internal logistics, redesigning workplaces, and changing the workplace layout.

(Received in November 2021, accepted in January 2022. This paper was with the authors 2 weeks for 1 revision.)
\end{abstract}

Key Words: Lean Concept, Lean Methods and Tools, SMEs, VSM, Simulation, Wastes of Assembly Line

\section{INTRODUCTION}

The main principle behind the Lean concept is based on creating value by eliminating activities that a customer is not willing to pay for, those that do not add value and lead to waste [1]. After World War 2 the Japanese automobile industry took advantage of the crisis it was faced with and managed to run its production with less money and time by modifying it. This led to lower losses and defects compared with the rivals. New philosophy, later known as the Toyota Production System (TPS), implied a just-in-time approach, the Kanban method, the pull system, poka-yoke, and many other methods and tools that were applied in the Toyota automobile industry when its manufacturing director was Taiichi Ohno. It took two decades for this philosophy and tools to be transferred to foreign markets, which was confirmed by the first book in English, published more than three decades later. The Toyota Company Director, Taiichi Ohno, identified seven types of waste as a consequence of various causes, the most common being overproduction, transport, waiting, excessive processing, inventory, unnecessary motion, and defects [2]. Another type of waste has been added recently, i.e., untapped human potential that results from mismanagement of human resources and inability to engage the employees within problem-solving teams.

Taking this into account, a claim can be made with certainty that the implementation of the Lean production concept, based on the Toyota Production System, in SMEs could lead to increased productivity and better chances at the global market. This is the reason why special research and analysis is needed in order to provide simple and practical guidelines for the implementation of the Lean concept in such companies.

A very small number of authors have tried to identify waste in the SMEs, present its impact, causal and consequential relationships, and offer solutions for its elimination by using the Lean tools in order to improve production processes. Also, a lot of companies do not manage to 
stabilize processes and production so as to eliminate waste (Jap. mura), which is a foundation to eliminate all waste (Jap. muri and muda) in the processes [1]. A number of studies have shown the effect of the Lean philosophy in particular production and service sectors, mostly eliminating waste and focusing on the customer value by using the VSM tool as a starting point to improve the production process [3]. Using such tools, many authors have presented improvements with certain problems and processes, but they could not create future solutions that would be applied as the following steps when designing new or redesigning the existing processes [4].

There are a lot of tools in practice that can be used for the identification, diagnosis, and implementation of initiatives to improve processes. However, the beginning of the evaluation process should start with process mapping, the so-called Value Stream Mapping [5]. The term value stream refers to everything necessary to transform input into a final product that creates value. Value is simply everything customers are ready to pay for. Taking a value stream perspective means working on a broader picture, not only on particular processes, i.e., the goal is to improve the whole, not only to optimize certain parts. The Value Stream Mapping is a tool that enables companies to achieve detailed visualization of all their activities and process, to detect waste points throughout the processes, and their cause. This tool allows for a holistic approach to the operation in the overall organizational system, but it can also be created for each product or service in all business areas. The Value Stream Mapping is based on the Toyota diagram of material and information stream. It provides efficient framework for presenting processes in a way that emphasizes waste and its negative impact on the overall performance and process flow. Furthermore, it has become a standard way of describing flow and it is a starting point for many Lean initiatives, comprising of three main components: material stream, information stream, and timeline.

Value Stream Mapping is one of the tools providing thorough insight and understanding of the process whilst it is possible to identify three types of activity [6, 7]:

- value-added activities (VA),

- non-value-added activities (NNVA), but are necessary for processes to function, and

- non-value-added activities (NVA), but are not necessary.

The VSM is applied with the aim to identify and eliminate the third type of activity, as it directly impacts waste and costs. Next, the causes of waste should be eliminated through the use of other Lean methods and tools. The VSM method is normally carried out in practice by means of the following steps [6,8]: mapping the current state of the process; analysis of the current process and possible improvement; the application of all improvements (by using particular Lean tools) and mapping the future state of the process.

The main research question is what kind of changes in production process provide the best results in eliminating wastes. As there are not many papers in the literature on the topic of simulations for eliminating waste in the SMEs, this article represents an important scientific contribution to filling this gap.

\section{LITERATURE REVIEW}

The term Lean has first appeared in the doctoral dissertation by Krafcik in 1988. Womack and Jones defined the initial concept of Lean in more detail in the book titled The Machine that Changed the World, which defined and described five key principles: create value for the customer, identify the value stream, create flow, produce only what is pulled by the customer, and pursue the perfection by continuous identification and elimination of waste $[9,10]$.

The main goal of the lean philosophy is to eliminate unnecessary activities that do not add value to the product. For the successful implementation of the lean philosophy, it is necessary to establish lean thinking in the company at all levels of the organisation, similar to TPS, which 
is based on principles and techniques of Just-in-Time (JiT) production and tools such as continuous improvement (Kaizen), Single-Minute Exchange of Die (SMED), value stream mapping, Six Sigma, and the "five S" method in order to remove waste and deliver improvements in specific areas [10,11].

Rother and Shook state that the VSM is one of the fundamental methods for implementing lean concept because it provides a visual representation of processes, material flow, information flow, and value flow $[6,7]$. In this way, we can transparently see which activities add value to the product and which do not because they represent waste [12].

Al-Aomar presented in his paper [13] an approach for the optimization of multi-lean measures by using simulation and Simulated annealing. Simulation has been used as a platform for the application of the Lean concept, in which the value stream mapping and the optimization of three performances (productivity, cycle time, and inventory level) by means of a case study would lead to the enhancement of the production process. Moreover, the advantage has been given to the implementation of the Lean concept in business systems which use dynamic modelling instead of static value stream mapping. This is exactly why many authors [14-18] combine the VSM and simulation software to confirm it in practice [19].

To improve the process of creating offers, Sremcev et al. [19] have introduced the system for the configuration of a new product by using VSM and discrete event simulation, with the simulation experiments emphasizing better performance of the new system in terms of accepted offer, use of resources, time of delivery, stream work, time without added value, and the number of needed operators. Some studies have shown excellent results after using only VSM [16, 17]. A number of authors have shown the use of VSM for the production of specific products, such as Yuvamitra et al. [20] or simulation of cost drive value stream mapping by Jordan et al. [18], with assumptions being made that the VSM is not able to present a number of process flows, visualize, and quantify all types of waste [19].

Also, one of the main problems in companies is flexibility. Ojstersek et al. have dealt with the impact of production flexibility on the sustainability of the production system, in regards with sustainable social, ecological, and financial impact of production. Complexity of parameter optimization is reflected in the multi-purpose nature which can be assessed by using the simulation research method [21]. It is known that SMEs are more flexible and that the implementation of the Lean concept can be more easily done than in large companies. However, owing to limited budgets of these companies, it has been suggested that they should use only achievable practices, but in no case all Lean tools at the same time [22]. On the other hand, the research has shown that, if the management uses only some of the Lean methods and tools, then the real potential benefits and continuous improvements are usually less productive [23].

In the last couple of decades, the Lean concept has often been a subject of research, although few authors, such as Tyagi [15], Achanga et al. [22], Kumar et al. [23], and Veza et al. [24] have stood for the implementation of the Lean production in SMEs. SMEs management cannot still ascertain what kind of tangible results and benefits it will lead to. Most companies fear that the implementation of the Lean production will be expensive and long lasting [22]. In comparison with large companies, the small ones have fewer resources and more difficult access to capital, but it has been confirmed that those SMEs that acquire the Lean concept achieve better competitiveness through faster innovation and production, increasing flexibility, and lower costs $[8,25,26]$.

Based on data from the Agency for Statistics, Bosnia and Herzegovina (B\&H) had 35,077 registered companies in 2019, of which $92.5 \%$ are small enterprises, $6.4 \%$ are medium-sized, and only $1.1 \%$ are large enterprises which employ more than 250 workers [27]. From the above data, in order to increase the productivity and competitiveness of SMEs, it is necessary to move to lean production processes, which could be closer to large companies in terms of efficiency and flexibility, although they lack knowledge, skills, finance, productivity and management 
[23, 25]. In addition, Achanga et al. [22] concludes in his paper that owing to limited resources SMEs are not capable of carrying out a great number of Lean tools at the same time.

It is exactly the application of Lean tools in future VSM and simulation of proposed solutions that enables fast check of improvements and the effect of flexibility on the sustainability of a system. Table I presents an overview of papers which used Lean methods and tools for waste elimination in production processes.

Table I: Lean methods and tools for waste elimination.

\begin{tabular}{|l|l|l|l|}
\hline \multicolumn{1}{|c|}{ Authors } & $\begin{array}{c}\text { Lean methods } \\
\text { and tools }\end{array}$ & \multicolumn{1}{|c|}{ Waste } & \multicolumn{1}{c|}{ Activities } \\
\hline Das [28] & Gemba & $\begin{array}{l}\text { Identifying all the eight } \\
\text { wastes }\end{array}$ & $\begin{array}{l}\text { Going where the problem is } \\
\text { encountered }\end{array}$ \\
\hline $\begin{array}{l}\text { Bal et al. [29] } \\
\text { Tyagi and Vadrevu } \\
\text { [15] } \\
\text { Takakuwa et al. [30] }\end{array}$ & VSM & $\begin{array}{l}\text { Identifying all the eight } \\
\text { wastes }\end{array}$ & Value flow mapping \\
\hline $\begin{array}{l}\text { Kumar et al. [21] } \\
\text { Pavnaskar et al. [31] }\end{array}$ & 5S & $\begin{array}{l}\text { Waiting; inventory; } \\
\text { unnecessary motion; } \\
\text { untapped human potential }\end{array}$ & $\begin{array}{l}\text { Improving the efficiency and } \\
\text { quality }\end{array}$ \\
\hline $\begin{array}{l}\text { Nguyen and Do [4] } \\
\text { Vegoy and Martin- }\end{array}$ & Kaizen & $\begin{array}{l}\text { Identifying all the eight } \\
\text { wastes }\end{array}$ & Continuous improvement \\
\hline $\begin{array}{l}\text { Al-Havari et al. [33] } \\
\text { Takakuwa et al. [30] }\end{array}$ & JiT; Kanban & $\begin{array}{l}\text { Identifying all the eight } \\
\text { wastes }\end{array}$ & $\begin{array}{l}\text { Continuous work flow between } \\
\text { the work stations }\end{array}$ \\
\hline Lazarevic et al. [34] & Poka Yoke & $\begin{array}{l}\text { Defects; waiting; } \\
\text { overproduction; untapped } \\
\text { human potential }\end{array}$ & $\begin{array}{l}\text { Fool-proofing technique for } \\
\text { error prevention and elimination }\end{array}$ \\
\hline Veza et al. [25] & Jidoka & Defects & $\begin{array}{l}\text { Automated shutdown of a } \\
\text { machine in the event of } \\
\text { detection of a defect automation } \\
\text { with human touch }\end{array}$ \\
\hline Leksic et al. [26] & $\begin{array}{l}\text { Standardization } \\
\text { of work }\end{array}$ & $\begin{array}{l}\text { Identifying all the eight } \\
\text { wastes } \\
\text { for each operator's work in the } \\
\text { production process. }\end{array}$ \\
\hline
\end{tabular}

Based on the analysis of the papers dealing with the application of Lean tools, it can be concluded that the authors have most often used case studies to analyse production processes $[8,11,14-18]$, and very few dealt with assembly processes. Nguyena and Do [4] presented the transformation process of a traditional production model into a Lean model, where a case study was performed about the Lean methods in reengineering the electronics assembly line. Reengineering was focused on some aspects, such as waste reduction and operation standardization. The paper reported positive results, which refer to almost $40 \%$ decrease of workforce with the same daily performance as well as reduction in average delivery time from 7.5 to 3 days [4]. By using the selective assembly method in their paper, Wang et al. [35] performed the optimization of precise product assembly to improve quality where very high precision assembly was needed, but without the application of the Lean tools.

\section{METHODOLOGY}

Based on the above, the following figure presents a model for the implementation of the Lean concept in SMEs (Fig. 1). 


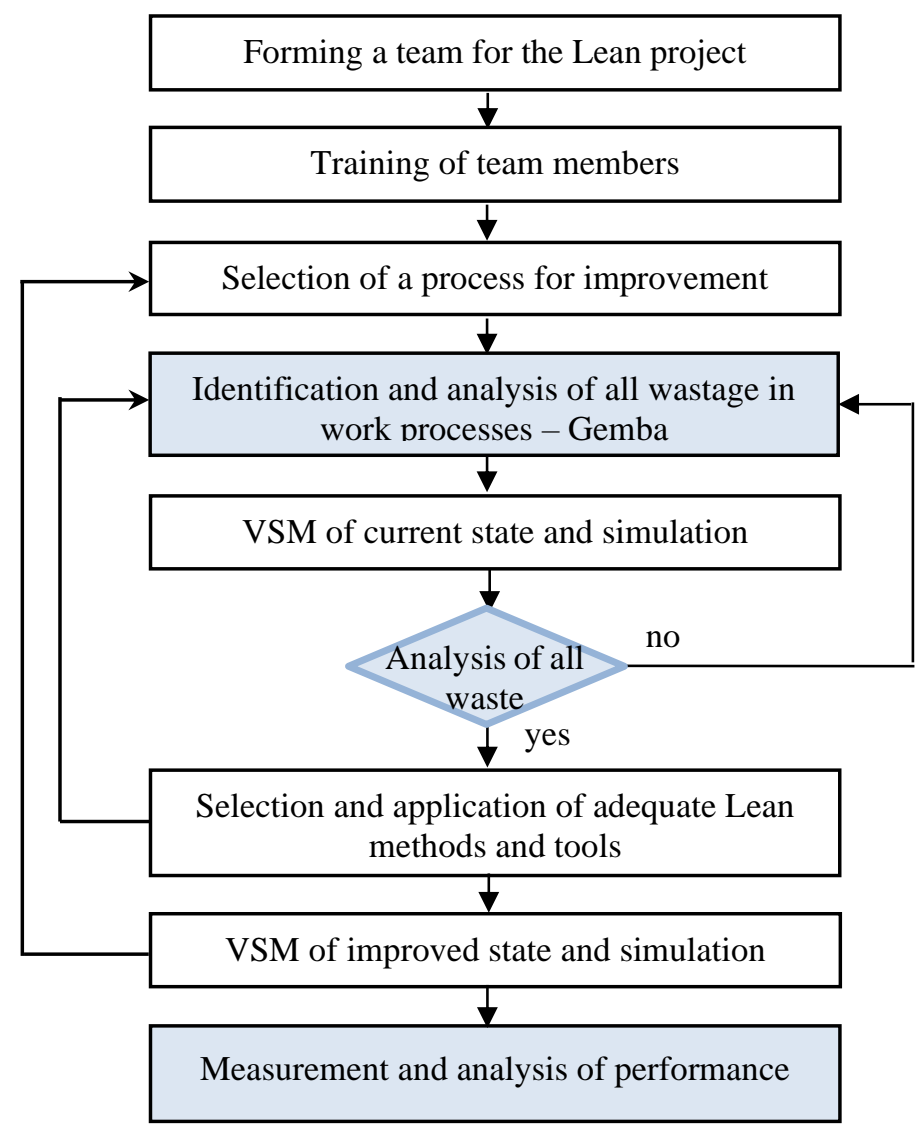

Figure 1: A model for the implementation of the Lean concept in SMEs with VSM and simulation.

\subsection{Forming a team for the lean project and training of team members}

A Lean project requires forming a team and training all team members. It is necessary to engage the best members of staff to deal with the observed processes in the team as they have the knowhow and competences. The team head should have leadership qualities, communication skills, ability to understand and analyse data, knowledge about the application of Lean tools and how various processes function in the company and how they are interrelated. To implement changes, it is necessary to include and motivate all employees in the company.

\subsection{Selection of a process for improvement}

The next question to be answered is which processes should be selected to be improved. It is important to focus on a single group of products, i.e., one production process (the ABC analysis or some other method can be used to select the group of products).

\subsection{Identification and analysis of all wastage in work processes (Gemba) and VSM of current state with simulation}

To identify and analyse the process, it is first necessary "to see the problem with one's one eyes, and then make a decision" [1,2] and get answers to the following questions: where waste and bottlenecks occur, how to improve material and information flow, how to reduce operative costs. Special attention should be paid to the collection of relevant data about processes [17]: Value-Added-Time, Lead Time, Cycle Time, Processing Time, Wait Time, Takt Time, Inventory Levels, Capacity, Percent Repaired, etc.

After all needed data are collected for the analysis, a thorough value stream mapping of the current state is performed. The current state of VSM shows the way material and information 
are being processed at the moment. Until the mapping of the current state is done, employees, including senior managers, are not aware of enormous wastage along the process, as well as the existence of bewildering information signals.

\subsection{Selection and application of adequate Lean methods and tools and VSM of improved state with simulation}

After specific waste is identified in the observed process, adequate Lean methods and tools are selected in order to reduce it. The selection of adequate Lean methods and tools can be made easier by using available literature dealing with types of wastage and its removal by using the said tools (Table I), as well as by referring to the experience of experts and members of teams for the implementation of the Lean project.

\subsection{Measurement and analysis of performance}

To manage processes efficiently, it is necessary to identify processes and key process indicators (KPI), because a wrong optimization criterion often leads to a solution which is not optimal. The implementation plan for process improvement is created based on the mapping of current state, which marks stream areas for the design of optimal processes. Every marking on the stream mapping is linked to the list of tasks that are needed to apply appropriate guidelines thoroughly. An improvement plan is designed by using Lean methods and tools with timedefined tasks and resources needed for their realization.

In order to answer the questions such as where wastage is formed (e.g., bottlenecks, inventory, etc.) and how to improve flow, i.e., how to reduce operative costs and inventory, it is important to follow the key indicators given below:

1. Value-Added-Time: Average total time needed to transform a product into value (waiting time not included).

2. Wait Time: Average time that a part / component waits along the process steps before it can move to the next step.

3. Processing Time: Average time needed to perform a processing operation on a single product within a single step.

4. Cycle Time: Average time needed from processing raw materials until the completion of end products ready for dispatch.

5. Lead Time: Average time from receiving a customer's order to delivery.

6. Inventory Levels: The number of individual pieces or parts waiting for processing within every step of the process.

7. Capacity: Average number of pieces or parts that a step in the process can produce by the unit of time.

8. Takt Time: Real rate of production in comparison with order rate.

\section{A CASE STUDY}

By using a case study, systemic approach, and the model created (Fig. 1), the aim of this paper is to identify and apply adequate tools for the implementation of the Lean concept in SMEs in order to remove waste, control inventory better, improve product quality, and control operation more efficiently. The model was applied in a company that employs 180 people.

Following the $\mathrm{ABC}$ analysis performed in relation with the value of dispatched products annually for the overall production program, the assembly process for the CITRUS, group of products (Fig. 2) was selected, with $41.5 \%$ share in the production program. CITRUS is a product used for squeezing fruits and vegetables. 

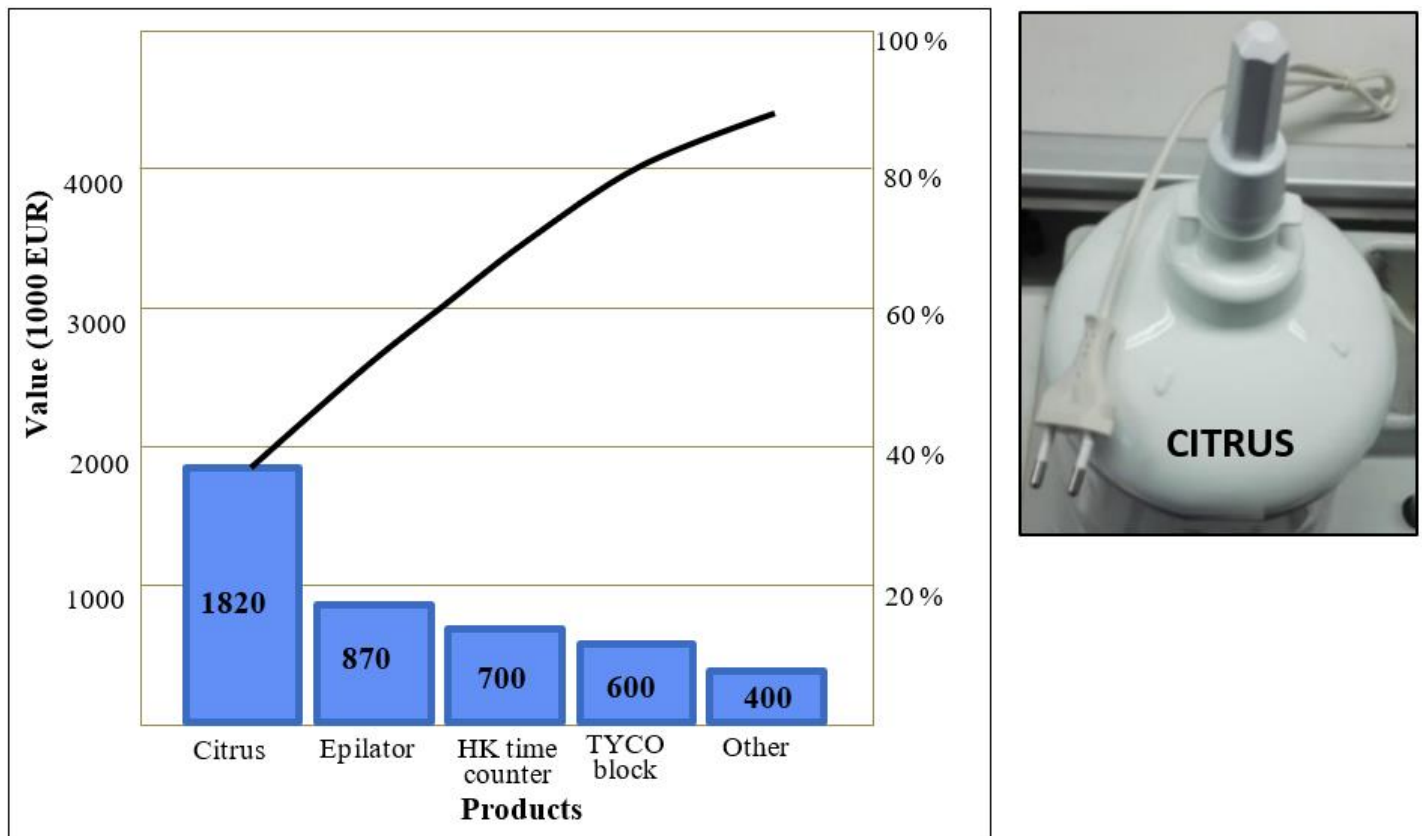

Figure 2: ABC analysis of a production program and selection of the process to be improved.

Relevant data were collected for the assembly of the CITRUS products (Table II), detailed simulation of the current state of the assembly process was performed in the Plant Simulation software (Fig. 3), and the current VSM created. The assembly line occupies an area of $41.7 \mathrm{~m}^{2}$ with eight workplaces that are not organized according to the order of the assembly process. Four workplaces are defined as assembly line work (WP1-WP4), two workplaces deal with soldering small and big contacts (WPVK and WPMK), and two (WPMP1 and WPMP2) deal with the assembly of MauntingPlateAssy subassembly.

Table II: List of parts for product assembly - CITRUS.

\begin{tabular}{|c|c|c|c|c|}
\hline No. & Operation & Work place & The name of the part & $\begin{array}{l}\text { Processing time } \\
(\mathrm{s} / \text { piece })\end{array}$ \\
\hline 1. & SolderingVK & WPVK & ConWireB35; ContactStrip & 11.70 \\
\hline 2. & SolderingMK & WPMK & ConWire52; ContactPiece & 11.50 \\
\hline $\begin{array}{l}3 . \\
4 .\end{array}$ & $\begin{array}{l}\text { AssemblyMauntingPlateAssy1, } \\
\text { WP - Pack190MP1 } \\
\text { AssemblyMauntingPlateAssy2, } \\
\text { WP - Pack190MP2 }\end{array}$ & WPMP2 & $\begin{array}{l}\text { MountingPlate; Axle; comp. } \\
\text { ComprSpring; SwitchSpring; } \\
\text { SolderingVK; SolderingMK }\end{array}$ & $\begin{array}{l}19.02 \\
19.02\end{array}$ \\
\hline 5. & Assembly 1 & WP1 & $\begin{array}{l}\text { MountingPlateAssy; Housing; } \\
\text { Motor; SpringSM; } \\
\text { Spindlegear; ContrGear }\end{array}$ & 19.00 \\
\hline 6. & Assembly 2 & WP2 & ConnWireB; CordSet & 16.13 \\
\hline 7. & Assembly 3 & WP3 & $\begin{array}{l}\text { HeadScrew; Bottom; } \\
\text { RubberStud }\end{array}$ & 16.47 \\
\hline 8. & $\begin{array}{l}\text { Assembly } 4 \text { and Control } \\
\text { Product unit Packing } \\
\text { Pack of } 20 \text { pieces of product }\end{array}$ & WP4 & $\begin{array}{l}\text { Spindle; } \\
\text { PEBag1; } \\
\text { MUPackaging20 }\end{array}$ & 14.23 \\
\hline
\end{tabular}




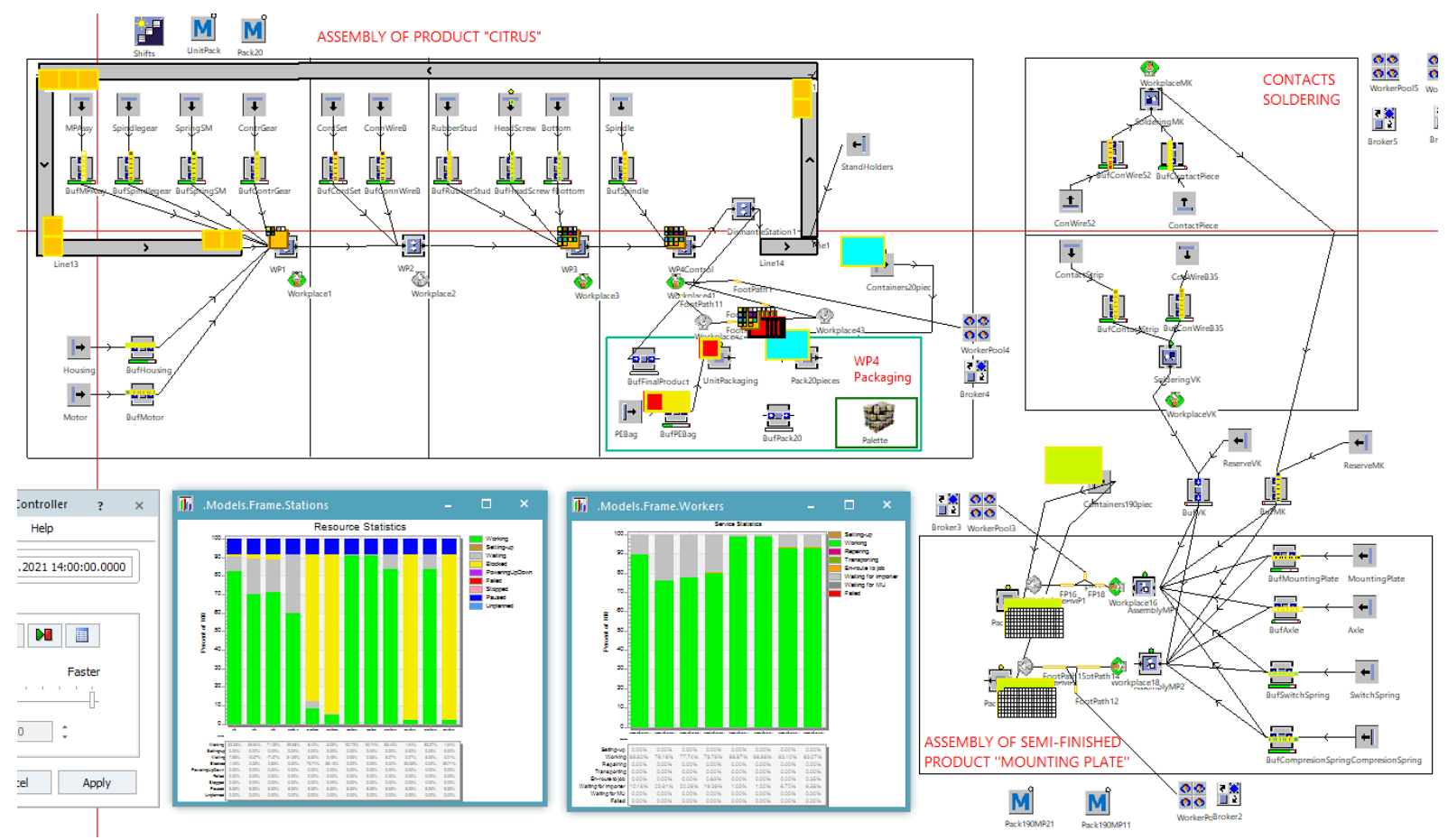

Figure 3: Simulation of the current state of the assembly line for the CITRUS products.

Based on the current VSM, waste was identified and adequate Lean tools were proposed to improve the current state (Table III), where the 5S method was applied first at all WPs.

Table III: Application of the Lean tools at the assembly line for the CITRUS products.

\begin{tabular}{|l|l|}
\hline Lean tools & \multicolumn{1}{|c|}{ Description of improvement } \\
Kaizen & $\begin{array}{l}\text { WPVK and WPMK - improving the contact } \\
\text { soldering process by introducing patterns, } \\
\text { whereby processing time was reduced. } \\
\text { PT_MK =11.7 (improved 8.7 s) and } \\
\text { PT_VK =11.5 s (improved 8.5 s) }\end{array}$ \\
\hline Heijunka & $\begin{array}{l}\text { At WP1 and WP2 process time was } \\
\text { levelled, i.e., the assembly of one part } \\
\text { (comprising 6 parts) (SpringGear) was } \\
\text { moved from WP1 to WP2 and with } \\
\text { additional kaizen processing time was } \\
\text { achieved: current (PT_WP1 } 19 \mathrm{~s} \text {, PT_WP2 } \\
\text { =16.13 s), improved: (PT_WP1 } 17 \mathrm{~s} \text {, } \\
\text { PT_WP2 PT =17.13 s). }\end{array}$ \\
\hline $\begin{array}{l}\text { Jidoka } \\
\text { PokaYoke } \\
\text { Kaizen }\end{array}$ & $\begin{array}{l}\text { At WP4 final control was improved by } \\
\text { introducing control sensors for main product } \\
\text { parameters, thus reducing processing time } \\
\text { by 1 s (from 14.23 s to 13.23 s) and number } \\
\text { of faulty products by 10\%. }\end{array}$ \\
\hline $\begin{array}{l}\text { Just in } \\
\text { Time } \\
\text { Kaizen }\end{array}$ & $\begin{array}{l}\text { As a result of previous improvements } \\
\text { production of sufficient number of pieces of } \\
\text { MountingPlate Assy at WPMP1 for the } \\
\text { assembly at WP1, which was not possible in } \\
\text { the current state. Also, at WP_MK and } \\
\text { WP_VK, after the improvement one worker } \\
\text { can make sufficient number of pieces of } \\
\text { SolderingMK and SolderingVK for the } \\
\text { assembly of MUPAssy, which was not } \\
\text { possible in the current state. }\end{array}$ \\
\hline
\end{tabular}


Fig. 4 shows future state of VSM with Lean tools applied in certain processes, whereas Fig. 5 presents an assembly line with a new layout of workplaces.

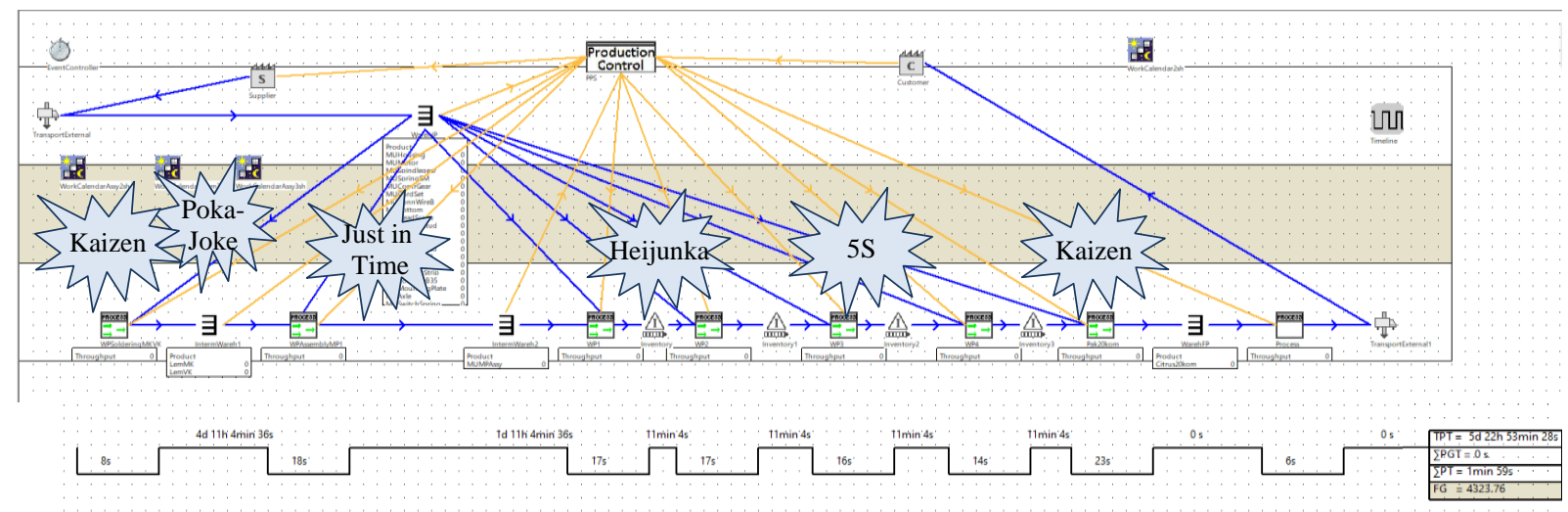

Figure 4: VSM of improved state of the CITRUS products.

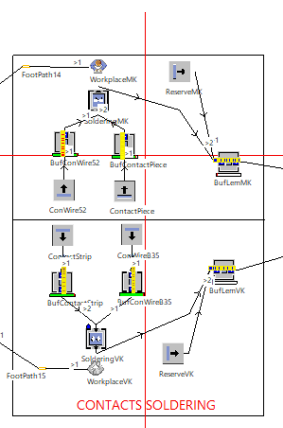

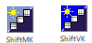

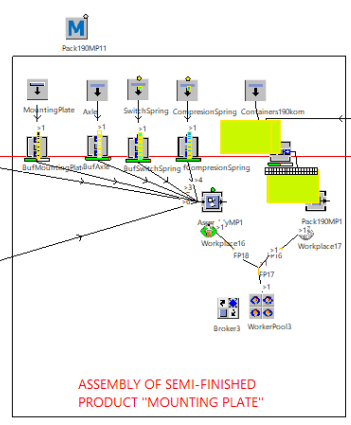

PRODUCT "MOUNTING PAAT"

Figure 5: Simulation of improved state of the CITRUS products assembly line.

\subsection{Comparative analysis of the current and future state}

Table IV presents significant statistical data of assembling the CITRUS products, for the current and future state, according to workplaces/ operations for one eight-hour shift (40 minutes breaks are included, $8.33 \%$ of the shift time).

Table IV: Resource statistics.

\begin{tabular}{|l|r|r|r|r|r|r|r|r|}
\hline \multirow{2}{*}{ Work Place } & \multicolumn{4}{|c|}{ Current state } & \multicolumn{4}{c|}{ Future state } \\
\cline { 2 - 10 } & Working & Waiting & Blocked & $\begin{array}{c}\text { Number } \\
\text { of exits }\end{array}$ & Working & Waiting & Blocked & $\begin{array}{c}\text { Number } \\
\text { of exits }\end{array}$ \\
\hline WP1 & $82.33 \%$ & $7.88 \%$ & $1.46 \%$ & 1247 & $79.92 \%$ & $8.54 \%$ & $3.21 \%$ & 1354 \\
\hline WP2 & $69.84 \%$ & $19.57 \%$ & $2.25 \%$ & 1247 & $80.48 \%$ & $7.90 \%$ & $3.29 \%$ & 1353 \\
\hline WP3 & $71.26 \%$ & $17.57 \%$ & $2.83 \%$ & 1246 & $77.32 \%$ & $10.82 \%$ & $3.53 \%$ & 1352 \\
\hline WP4Control & $59.68 \%$ & $31.99 \%$ & $0.00 \%$ & 1245 & $60.05 \%$ & $31.62 \%$ & $0.00 \%$ & 1351 \\
\hline UnitPackaging & $8.42 \%$ & $3.50 \%$ & $79.74 \%$ & 1245 & $9.14 \%$ & $3.55 \%$ & $78.98 \%$ & 1351 \\
\hline Pack20pieces & $5.03 \%$ & $0.48 \%$ & $86.15 \%$ & 62 & $5.43 \%$ & $0.52 \%$ & $85.71 \%$ & 67 \\
\hline WP SolderingVK & $90.74 \%$ & $0.93 \%$ & $0.00 \%$ & 2233 & $44.90 \%$ & $0.93 \%$ & $0.00 \%$ & 1486 \\
\hline WP SolderingMK & $90.72 \%$ & $0.95 \%$ & $0.00 \%$ & 2271 & $44.88 \%$ & $0.95 \%$ & $0.00 \%$ & 1520 \\
\hline WP AssemblyMP1 & $83.40 \%$ & $8.27 \%$ & $0.00 \%$ & 1291 & $89.43 \%$ & $2.24 \%$ & $0.00 \%$ & 1384 \\
\hline Pack190MP1 & $1.94 \%$ & $0.07 \%$ & $89.65 \%$ & 6 & $2.22 \%$ & $0.07 \%$ & $89.37 \%$ & 7 \\
\hline WP AssemblyMP2 & $83.37 \%$ & $8.29 \%$ & $0.00 \%$ & 1290 & & & & \\
\hline Pack190MP2 & $1.94 \%$ & $0.01 \%$ & $89.71 \%$ & 6 & & & & \\
\hline
\end{tabular}


By using Lean methods and tools, improvement was achieved in terms of reduced number of workplaces, lower inventory, and processing assembly time, as shown in Tables V and VI.

Table V: Inventory between processing steps before and after improvement.

\begin{tabular}{|c|c|c|}
\hline Place of inventory & Current state (units) & Future state (units) \\
\hline Between WPSolderingMK and WPAssemblyMP1 & 250 & 290 \\
\hline Between WPSolderingVK and WPAssemblyMP1 & 250 & 290 \\
\hline Between WPSolderingMK and WPAssemblyMP2 & 250 & 0 \\
\hline Between WPSolderingVK and WPAssemblyMP2 & 250 & 0 \\
\hline Between WPAssemblyMP1 and WP1 & 350 & 190 \\
\hline Between WPAssemblyMP2 and WP1 & 350 & 0 \\
\hline Between WP1 and WP2 & 1 & 1 \\
\hline Between WP2 and WP3 & 1 & 1 \\
\hline Between WP3 and WP4Control & 2 & 1 \\
\hline Between WP4Control and Pack20pieces & 0 & 0 \\
\hline Total & 1704 & 773 \\
\hline
\end{tabular}

Table VI: Comparison of Lean metrics before and after improvement by VSM.

\begin{tabular}{|l|c|c|c|}
\hline \multicolumn{1}{|c|}{ Feature } & $\begin{array}{c}\text { Current state VSM } \\
\text { (units) }\end{array}$ & $\begin{array}{c}\text { Future state VSM } \\
\text { (units) }\end{array}$ & $\begin{array}{c}\text { Improvement } \\
\text { (\%) }\end{array}$ \\
\hline $\begin{array}{l}\text { Total processing time with } \\
\text { added value }\left(\sum P T\right)\end{array}$ & $\begin{array}{c}2 \mathrm{~min} 7 \mathrm{~s} \\
(2.116 \mathrm{~min})\end{array}$ & $\begin{array}{c}1 \mathrm{~min} 59 \mathrm{~s} \\
(1.983 \mathrm{~min})\end{array}$ & 6.285 \\
\hline $\begin{array}{l}\text { Total inventory and transport } \\
\text { line }(T P T) \text { flow }\end{array}$ & $\begin{array}{c}13 \mathrm{~d} 2 \mathrm{~h} 46 \mathrm{~min} 6 \mathrm{~s} \\
(18886.1 \mathrm{~min})\end{array}$ & $\begin{array}{c}5 \mathrm{~d} 22 \mathrm{~h} 53 \mathrm{~min} 28 \mathrm{~s} \\
(8573.467 \mathrm{~min})\end{array}$ & 54.60 \\
\hline $\begin{array}{l}\text { Static flow speed }(F G) \\
\left(\sum P T+T P T\right) / \sum P T\end{array}$ & 8923.57 & 4323.76 & 51.55 \\
\hline $\begin{array}{l}\text { VA ratio } \\
\left(\sum P T /\left(\sum P T+T P T\right)\right) \times 100 \%\end{array}$ & $0.011 \%$ & $0.023 \%$ & \\
\hline
\end{tabular}

\section{CONCLUSION}

The paper presents the model for the implementation of the Lean concept in SMEs and the case study for the improvement of a production process for the CITRUS products with a focus on reducing non value-added activity (NVA), cycle time, and increasing productivity by applying VSM and other Lean methods and tools. It can be concluded that VSM, kaizen, 5S, jidoka, poka yoke, and operation standardization are main tools for the identification and reduction of process waste. Taking into consideration technical suitability, economic rationale, and feasibility analysis, a set of tools has been proposed as a means of efficient introduction of the Lean concept in SMEs with the aim to deliver products faster and in a more quality manner. Based on the analysis aimed at improving the CITRUS assembly line process through the implementation of lean methods and tools and the application of simulations for the future, we achieved the research objectives, i.e. which changes give the best results in terms of lean concept application.

According to the analysis based on the simulation of the current state, VSM does not only increase the service level for the customer, but it also reduces work-in process (WIP) inventory. Total WIP inventory of values stream has been reduced from 1704 to 773 units $(54.60 \%)$. The greatest impact of the reduction of inventory has been on the reduction of workplace number to WP_MK, WP_VK and WP_MPAssy. Since two workers needed to work in two shifts occasionally in order to provide inventory, and produced number of parts have not been used at once, but in the following days when workers worked at the said WPs in one shift, this resulted in increased inventory. The application of the $5 \mathrm{~S}$ method was of great importance for 
achieving good results in the work, because the reorganization of jobs on the assembly line was carried out. The five $\mathrm{S}$ methods aim to rationalize the company's space as much as possible and eliminate all unnecessary movements of workers, so that in the proposed assembly line, each workplace was organized respecting the principles of this method.

In the case study the selected improvement processes can be changed at any level without additional costs. This means that for the given case the company can simulate mapping of the future state in order to achieve Lean production without any financial burden. Although Lean principles are often generic, the proposed case study is rarely found in the literature and points to an innovative application. Considering good results obtained, the proposed methodology is very relevant scientifically, as it can also be easily applied to similar production processes or assembly in SMEs with single-unit and small-scale production.

\section{REFERENCES}

[1] Liker, J. K. (2004). The Toyota Way: 14 Management Principles from the World's Greatest Manufacturer, McGraw-Hill Education, New York

[2] Womack, J. (2013). Gemba Walks, $2^{\text {nd }}$ edition, Lean Enterprise Institute, Boston

[3] Hines, P.; Found, P.; Griffiths, G.; Harrison, R. (2011). Staying Lean: Thriving Not Just Surviving, $2^{\text {nd }}$ edition, Productivity Press, New York

[4] Nguyen, M.-N.; Do, N.-H. (2016). Re-engineering assembly line with lean techniques, Procedia CIRP, 590-595, doi:10.1016/j.procir.2016.01.139

[5] Alston, F. (2017). Lean Implementation Applications and Hidden Costs, CRC Press, Boca Raton

[6] Rother, M.; Shook, J. (1999). Learning to See: Value Stream Mapping to Create Value and Eliminate Muda, Lean Enterprise Institute, Boston

[7] Rother, M.; Shook, J. (2003). Learning to See: Value-Stream Mapping to Add Value and Eliminate $M u d a, 2^{\text {nd }}$ edition, Lean Enterprise Institute, Cambridge

[8] Antony, J.; Vinodh, S.; Gijo, E. V. (2016). Lean Six Sigma for Small and Medium Sized Enterprises: A Practical Guide, CRC Press, Boca Raton

[9] Womack, J. P.; Jones, D. T.; Ross, D. (1991). The Machine that Changed the World: The Story of Lean Production, Harper Perennial, New York

[10] Hicks, B. J. (2007). Lean information management: understanding and eliminating waste, International Journal of Information Management, Vol. 27, No. 4, 233-249, doi:10.1016/ j.ijinfomgt.2006.12.001

[11] Radošević, M.; Ćosić, I.; Soković, M.; Marković, J.; Rikalović, A.; Kušar, J. (2013). Improvement of education work process quality by applying VSM - Lean tools, Technics Technologies Education Management, Vol. 8, No. 2, 676-681

[12] Trebuna, P.; Pekarcikova, M.; Edl, M. (2019). Digital value stream mapping using the Tecnomatix Plant Simulation software, International Journal of Simulation Modelling, Vol. 18, No. 1, 19-32, doi:10.2507/IJSIMM18(1)455

[13] Al-Aomar, R. (2011). Handling multi-lean measures with simulation and simulated annealing, Journal of the Franklin Institute, Vol. 348, No. 7, 1506-1522, doi:10.1016/j.jfranklin.2010.05.002

[14] Radošević, M.; Ćosić, I.; Soković, M.; Božičković, R. (2011). Value stream mapping - visualise before acting, Proceedings of the XV International Scientific Conference on Industrial Systems, 44-47

[15] Tyagi, S.; Vadrevu, S. (2015). Immersive virtual reality to vindicate the application of value stream mapping in an US-based SME, The International Journal of Advanced Manufacturing Technology, Vol. 81, No. 5, 1259-1272, doi:10.1007/s00170-015-7301-1

[16] Dushyanth, K. K. R.; Shivashankar, G. S.; Rajeshwar, S. K. (2015). Application of value stream mapping in pump assembly process: a case study, Industrial Engineering \& Management, Vol. 4, No. 3, Paper 1000162, 11 pages, doi:10.4172/2169-0316.1000162

[17] Rahani, A.-R.; Al-Ashraf, M. (2012). Production flow analysis through value stream mapping: a lean manufacturing process case study, Procedia Engineering, Vol. 41, 1727-1734, doi:10.1016/j.proeng.2012.07.375 
[18] Jordan, E.; Berlec, T.; Rihar, L.; Kusar, J. (2020). Simulation of cost driven value stream mapping, International Journal of Simulation Modelling, Vol. 19, No. 3, 458-469, doi:10.2507/IJSIMM193-527

[19] Sremcev, N.; Stevanov, B.; Lazarevic, M.; Mandic, J.; Tesic, Z.; Kuzmanovic, B. (2019). Improving process of quotation creation through value stream mapping and simulation, International Journal of Simulation Modelling, Vol. 18, No. 4, 563-573, doi:10.2507/ IJSIMM18(4)484

[20] Yuvamitra, K.; Lee, J.; Dong, K. (2017). Value stream mapping of rope manufacturing: a case study, International Journal of Manufacturing Engineering, Vol. 2017, Paper 8674187, 11 pages, doi: $10.1155 / 2017 / 8674187$

[21] Ojstersek, R.; Acko, B.; Buchmeister, B. (2020). Simulation study of a flexible manufacturing system regarding sustainability, International Journal of Simulation Modelling, Vol. 19, No. 1, 6576, doi:10.2507/IJSIMM19-1-502

[22] Achanga, P.; Shehab, E.; Roy, R.; Nelder, G. (2006). Critical success factors for lean implementation within SMEs, Journal of Manufacturing Technology Management, Vol. 17, No. 4, 460-471, doi:10.1108/17410380610662889

[23] Kumar, M.; Antony, J.; Singh, R. K.; Tiwari, M. K.; Perry, D. (2006). Implementing the Lean Sigma framework in an Indian SME: a case study, Production Planning \& Control, Vol. 17, No. 4, 407-423, doi:10.1080/09537280500483350

[24] Veza, I.; Mladineo, M.; Gjeldum, N. (2016). Selection of the basic Lean tools for development of Croatian model of innovative smart enterprise, Tehnicki vjesnik - Technical Gazette, Vol. 23, No. 5, 1317-1324, doi: $10.17559 / \mathrm{tv}-20160202120909$

[25] Tanasić, Z.; Janjić, G.; Kosec, B. (2019). Lean concept in small and medium enterprises, $R M Z$ Materials and Geoenvironment, Vol. 66, No. 2, 129-137, doi:10.2478/rmzmag-2019-0010

[26] Leksic, I.; Stefanic, N.; Veza, I. (2020). The impact of using different lean manufacturing tools on waste reduction, Advances in Production Engineering \& Management, Vol. 15, No. 1, 81-92, doi:10.14743/apem2020.1.351

[27] Agency for Statistics of Bosnia and Herzegovina. Bosnia and Herzegovina in figures, 2020, from https://bhas.gov.ba/?lang=en, accessed on 16-10-2021

[28] Das, K. (2018). Integrating lean systems in the design of a sustainable supply chain model, International Journal of Production Economics, Vol. 198, 177-190, doi:10.1016/ j.ijpe.2018.01.003

[29] Bal, A.; Ceylan, C.; Taçoğlu, C. (2017). Using value stream mapping and discrete event simulation to improve efficiency of emergency departments, International Journal of Healthcare Management, Vol. 10, No. 3, 196-206, doi:10.1080/20479700.2017.1304323

[30] Takakuwa, S.; Yang, W.; Nagatsuka, H. (2018). Learning the procedure on takt production of TPS by methods engineering and simulation, International Journal of Simulation Modelling, Vol. 17, No. 4, 633-642, doi:10.2507/IJSIMM17(4)452

[31] Pavnaskar, S. J.; Gershenson, J. K.; Jambekar, A. B. (2003). Classification scheme for lean manufacturing tools, International Journal of Production Research, Vol. 41, No. 13, 3075-3090, doi:10.1080/0020754021000049817

[32] Uzsoy, R.; Martin-Vega, L. A. (1990). Modeling Kanban-based demand-pull systems: a survey and critique, Manufacturing Review, Vol. 3, No. 3, 155-160

[33] Al-Hawari, T.; Aqlan, F.; Al-Araidah, O. (2010). Performance analysis of an automated production system with queue length dependent service rates, International Journal of Simulation Modelling, Vol. 9, No. 4, 184-194, doi:10.2507/IJSIMM09(4)2.168

[34] Lazarevic, M.; Mandic, J.; Sremcev, N.; Vukelic, D.; Debevec, M. (2019). A systematic literature review of Poka-yoke and novel approach to theoretical aspects, Strojniski vestnik - Journal of Mechanical Engineering, Vol. 65, No. 7-8, 454-467, doi:10.5545/sv-jme.2019.6056

[35] Wang, W.; Li, D. B.; He, F.; Tong, Y. F. (2018). Modelling and optimization for a selective assembly process of parts with non-normal distribution, International Journal of Simulation Modelling, Vol. 17, No. 1, 133-146, doi:10.2507/IJSIMM17(1)CO1 